\title{
'Safeguarding' as humanitarian buzzword: an initial scoping
}

Kristin Bergtora Sandvik ${ }^{1,2}$

\begin{abstract}
Suddenly, talk of 'safeguarding' and a sector-wide 'safeguarding crisis' seems to be everywhere. Grappling with the scope and content of 'safeguarding' as a parameter of humanitarian practice, this commentary asks questions about the framing of safeguarding as a buzzword: about what buzzwords do, whether safeguarding is a global buzzword, whether it is a reframing of old concerns and historical accountability efforts, what is new about it-and finally, what kind of reflections and responses this newness should engender.
\end{abstract}

Keywords: Buzzwords, Humanitarian accountability, Safeguarding, Sexual exploitation, Sexual violence

\section{Introduction}

Suddenly, talk of 'safeguarding' and of a sector-wide 'safeguarding crisis' seems to be everywhere. In the wake of the Oxfam scandal in Haiti, where the organization is perceived to have failed to act on sexual misconduct by staff in the aftermath of the 2010 earthquake and then to have attempted a cover-up, the aid sector is now engaging in 'safeguarding' exercises (BBC 2018). While initially based on a UK legal definition that applied to vulnerable adults and children, safeguarding has acquired a broader meaning, which includes all actions by aid actors to protect staff from harm (abuse, sexual harassment and violence) and to ensure staff do not harm beneficiaries. ${ }^{1}$ As observed by Bruce-Raeburn (2018a), this is common practice: the aid sector has 'careened from one theory of change to another, all the while leaving a trail of buzzwords, jargon, and concepts'. In 2018, 'and without missing a beat', Bruce-Raeburn notes, 'safeguarding joined the aid sector lexicon' (Bruce-Raeburn 2018a). Considering the scope and content of 'safeguarding' as a parameter of humanitarian practice, this commentary asks questions about the framing of safeguarding as a buzzword. ${ }^{2}$

I do not claim that this piece is exhaustive or the 'best' way to think about safeguarding. Due to its format, it does not provide a full survey of sources and references. My aim is to reflect critically on what the 'safeguarding'

\footnotetext{
Correspondence: bergtora@prio.no

${ }^{1}$ PRIO, PO Box 9229, Grønland, 0134 Oslo, Norway

2Department of Criminology and Sociology of Law, University of Oslo, Oslo,
} Norway

\section{What do buzzwords do?}

As Cornwall and Brock (2005) explain, buzzwords confer the legitimacy aid actors need to justify their interventions. Buzzwords frame problems by singling out some aspects of a situation and thereby defining courses of action. Buzzwords are used to create problem statements that by their nature call for certain kinds of solutions. Successful buzzwords engender institutional and economic consequences: According to Dijkzeul (2015), 
such issues as sexual violence in war go from being unrecognized, ignored or forgotten to becoming an industry that appropriates funding, taking attention and resources away from other humanitarian needs and problems, and from addressing root causes.

Has safeguarding become a global buzzword? While safeguarding is clearly in the early stages of following the buzzword trajectory, the tentative answer is 'no'-or at least 'not yet'. It remains a buzzword largely confined to certain humanitarian policy arenas in the Global North. Safeguarding, together with a series of high-profile sexual exploitation scandals, originated in the UK: the UK government and large UK NGOs are the industry leaders institutionalizing the concept through contentious 'safeguarding summits' (Gov.UK 2018a) that have led to protests and boycotts by activists (Parker 2018). As part of its response, the UK government has launched a new Interpol/Save the Children coordinated vetting project, Soteria, that will provide criminal record checks and improve information sharing (Gov.UK 2018b).

Nevertheless, while sexual misconduct has moved to the top of most agencies' policy and public relations agenda, there are wide variations in terminology and problem-framing across the sector. For example, when, in spring 2018, 118 members of InterAction (a US NGO alliance) signed a pledge on preventing sexual abuse, and exploitation by and of NGO staff, the word 'safeguarding' was not used (Interaction 2019). The ICRC has decided to continue to use 'sexual violence prevention and response', and 'sexual misconduct' in the Code of Conduct (as I learned from a conversation with an anonymous aid worker). The IFRC uses 'sexual and gender-based violence'. The decision not to adopt 'safeguarding' as a buzzword appears to be partly to do with the fact that 'safeguarding' can relate to many other projects and problems: the ICRC has, for instance, drawn attention to the importance of 'safeguarding healthcare' (ICRC 2016). The IFRC uses 'safeguarding' to describe a range of priorities, including youth policy and environmental protection (IFRC n.d.; IFRC 2018).

Safeguarding has also been a commonly used concept in international aid: for example, it is employed by the World Bank with respect to environmental and social frameworks (World Bank 2016). At the same time, the notion of safeguarding has already been severely criticized for its lack of inclusiveness and for being yet another costly top-down initiative (Bruce-Raeburn 2018a) designed to save the face of large organizations, where the safeguarding industry was hatched and experts magically appeared and promises of change were made' with little attention to local and national context or participation (Bruce-Raeburn 2018b).

\section{Is safeguarding new?}

To understand the broader context of safeguarding, it is necessary to ask, what is old? At its core, the idea of safeguarding is to reinforce the humanitarian imperative to do no harm, by preventing 'sexual abuse and exploitation'. As I will explain below, humanitarians have long been concerned about this and tried to do something about it. However, when one examines the struggles of the humanitarian sectors over the past decades-my frame of reference goes back to the early-mid 1990s, while that of others will be longer or shorter than thatit becomes clear that safeguarding can also be thought of as the label currently put on an ongoing crisis of legitimacy. In broad terms, safeguarding then becomes the latest instalment of the three-decade long humanitarian accountability project (Jacobsen and Sandvik 2016; Sandvik 2016).

Humanitarian accountability first emerged as a concern in the 1980s and was institutionalized through the 1994 Code of Conduct for the International Red Cross and Red Crescent Movement and NGOs in Disaster Relief (ICRC 1994). The findings of the 1996 Joint Evaluation of Emergency Assistance to Rwanda represented a defining moment in the understanding of humanitarian accountability (Borton 2004) and resulted in several sector-wide initiatives. The Sphere Project, launched in 1997, focuses on both humanitarian ethics via the Humanitarian Charter and technical regularization of humanitarian action through the Minimum Standards in Disaster Response (Nadig 2012) and continues to provide guidance to the sector through updated handbooks. Other accountability initiatives, like HAP International (the Humanitarian Accountability Project) and People in Aid also emerged (these two became the CHS alliance in 2015), and eventually, humanitarian accountability became a separate mini-industry within the sector. Efforts to streamline the sector's accountability initiatives culminated in 2014 with the revised Core Humanitarian Standards (CHS Alliance 2019). Throughout this period, sexual exploitation has been considered the worst possible behaviour humanitarian workers can be guilty of, but it has not been clear what constitutes exploitation and which relationships exploitation takes place in (Sandvik 2018).

The next question is 'what is new'? While there might be disagreement as to the historical trajectory and geographical scope of 'safeguarding', it also appears that something is new in the landscape surrounding safeguarding and that this newness will inevitably impact its content. Central to this are the rapidly evolving and sometimes overlapping global political and legal initiatives addressing sexual exploitation, harassment and prostitution. A useful way to scope 'newness', therefore, is to map out the changing policy contexts of the sexual exploitation of beneficiaries, the sexual harassment of subordinates and co-workers, the acquisition of commercial sexual services and, finally, the general technologization of humanitarian space. 


\section{A changing global morality}

I suggest that safeguarding must be understood in the context of significant changes over the last 25 years in the standards of global public morality regarding the conduct of personnel working for international organizations and NGOs when vulnerable adults and children are involved. In Phnom Penh in 1992, in his only policy statement on sexual activity by personnel, Yasushi Akashi, head of the UN peacekeeping mission UNTAC (United Nations Transitional Authority in Cambodia) said in a staff meeting that young men needed to have fun, i.e. buy sex, and that 'boys will be boys' (although UNTAC staff were told not to park UN vehicles in front of brothels) (Ledgerwood 1994). However, since then, the normative perspectives and positions of international organizations have rapidly evolved, at least on paper. UNHCR's 1995 guidelines on sexual violence and refugees expressly mentioned 'international refugee workers' as being implicated in sexual violence against refugees (UNHCR 1995).

In 2002, the joint UNHCR and Save the Children UK report on the sexual exploitation of refugee children in West Africa documented allegations against 40 agencies and 67 individuals (Naik 2002). In 2003, in a wording that now seems odd, the Secretary General's bulletin ST/ SGB/2003/13, which set out special measures for protection from sexual exploitation and sexual abuse, noted that these acts constitute serious misconduct and grounds for disciplinary measures: 'Sexual relationships between United Nations staff and beneficiaries of assistance' are 'based on inherently unequal power dynamics'. They 'undermine the credibility and integrity of the work of the United Nations'-and in consequence, they are 'strongly discouraged' (Secretary General 2003). In continuation of the work to protect vulnerable adults and children, during the past 15 years, the humanitarian sector has seen a flurry of institutional initiatives and shifting acronyms. The effort to prevent sexual exploitation and abuse is now commonly known by the acronym 'PSEA' and is led by the IASC (Inter-Agency Standing Committee). ${ }^{3}$

\section{Women's rights and MeToo}

Safeguarding has emerged at a key historical moment for women's rights, as well as for the humanitarian sector. The current 'safeguarding crisis' follows a global MeToo movement that has had a particularly significant impact in some of the biggest donor countries in the Global North, highlighting a high level of sexual exploitation and harassment, as well as widespread impunity. Sexual harassment in the workplace is no longer something that is just officially frowned on: it is increasingly considered to undermine workers' labour rights and to be highly detrimental to effectiveness, output and reputation. For the humanitarian sector, this means that concern about protection against predatory behaviour now goes beyond the relationship between aid worker and beneficiary, to encompass workplace relations between seniors and juniors, as well as between individuals where no formal hierarchical relationship exists. At the same time, the response to sexual harassment is also shaped by broader trends in the humanitarian sector: the professionalization and legalization of aid work (Lohne and Sandvik 2017) and the emergence of a duty of care standard for humanitarian workers (Merkelbach and Kemp 2016; Sandvik 2019), including the application of domestic labour law protection against abusive bosses and co-workers (Fairbanks 2018). In tandem with this (and in interesting contrast to the focus on beneficiary resilience), there has been an emergence of a US-inspired 'humanitarian wellness' language and wellness training for humanitarians with a focus on self-care (Humanitarianwellbeing n.d.)

\section{A vanishing distinction between transactional and exploitative sex}

The interpretation of what safeguarding means is also shaped by changing cultural perceptions of transactional sex and prostitution, primarily in the Global North. While the MeToo campaign is of very recent date, it links up with a more longstanding trend in big donor countries, namely the de facto criminalization of prostitution by criminalizing the buyer. Whereas Codes of Conduct have been promoted as a key mechanism for governing the sexual behaviour of humanitarian workers (Matti 2015), the act of buying sex is increasingly construed legally and ideologically as a criminal practice. ${ }^{4}$ In my view, this is possibly the most difficult field of social practice covered by safeguarding, and where it is vital to think carefully so that one can tread the fine line between justifiable moral censure and moralistic outrage. Is moralistic outrage necessarily a bad thing? The view appears to be an emerging that paying for sex, anywhere and at any time, is incompatible with being a 'good' humanitarian worker and dependable employee; the distinction between paying for sex and exploiting someone for sex is being erased. ${ }^{5}$

While buying sex in the 1980s, for example, appears to have been a fairly common practice in the aid world (broadly defined), much of the moral indignation previously linked to prostitution and aid was linked to the HIV/AIDS epidemic and the fact that buying sex helped spread the epidemic at home and abroad (Ledgerwood 1994). Today, in such donor countries as Canada, France, Iceland, Ireland, Norway and Sweden, buying sex is illegal and is punished with fines or prison sentences (Procon.org 2018). At the same time, criminalization remains extremely controversial. Global 
prostitution activism has long been an ideological battlefield, with a seemingly unbridgeable abyss between those who see prostitution as violence against women and those who want it regulated as work, regardless of gender. While I am not aware of any comprehensive effort to track the consequences of criminalization for sex workers, new research indicates that vulnerable women in prostitution become more vulnerable through criminalization in the Global North (Jahnsen and Skilbrei 2017; Skilbrei 2018). Thus, when trying to gauge an appropriate scope for the idea of safeguarding, it is necessary to reflect on the usefulness (and normative appropriateness) of maintaining a conceptual distinction between procuring sexual services from a beneficiary or vulnerable person-and buying them from sex workers not positioned as recipients or as being in a position of vulnerability in the humanitarian field.

\section{Can safeguarding be technologized?}

A final point concerns the current humanitarian recourse to technology (Sandvik et al. 2014) and the how of safeguarding regulations. As critics, we must be alert to efforts to 'technologize' safeguarding responses. Increasingly, humanitarian action is being quantified and remotely controlled (Duffield 2016; Jacobsen and Sandvik 2016). The Soteria initiative mentioned above serves as a good example of this trend. The demand for measurements and 'evidence-based approaches' engender a framing of social life and its problems that lends itself to a focus on aspects of 'the social' that can be counted and classified (or be made classifiable and countable). This emphasis on quantification may engender a reductive form of accountability resulting from distilling social life into excessively 'neat categories' (Merry 2016). In a parallel but closely related development, surveillance is becoming an increasingly common technique of humanitarian governance (Dijkzeul and Sandvik 2019). While the stated objective of equipping humanitarian workers with tracking devices is to protect missions in an increasingly fractured humanitarian space (for an example, see the iTrack n.d.), this approach raises difficult ethical questions (O’Mathúna et al. 2018) about privacy and work/life balance. It also risks creating a sense of complacency, if agencies rely on number crunching and digital processes to tell them what kind of risk their workers constitute (their profile), where their workers are (their location on a map) and what they are doing (legible actions that produce data). None of these remote-control strategies correspond meaningfully to the need to reduce power imbalances and empower those in precarious positions, be they beneficiaries or staff.

\section{Conclusions}

The aim of this commentary has been to show how safeguarding means different things to different people, depending on where they are situated within the aid sector: variations are based on gender, nationality, geographical location and age. Hence, understanding 'safeguarding' as a normative bundle based on humanitarian sector-specific responses to 'internal' events in the humanitarian space as well as to broader social, cultural and political developments, is perhaps the best way of coming to terms with its meaning and potential impact on the sector.

In conclusion, as has been indicated, there is nothing 'obvious' about the content of the safeguarding concept or how it is being mainstreamed. Charges of face-saving and tokenism - the view that safeguarding is yet another Western-centric practice, and frustrated complaints about the absence of meaningful field participation and local consultations when safeguarding approaches are formulated need to be taken seriously and addressed carefully. There is also a trade-off: making policies more comprehensive, in terms of who is protected against what, and who is responsible for taking which precautionary measures and/or imposing what type of sanctions, raises difficult questions about personal liberties and the scope of humanitarian morality. At the same time, on an institutional level, agencies that claim an absence or near absence of harassment, sexual exploitation and violence now appear suspect-and not on top of their duty of care obligations. A practical first step for holding agencies accountable is to require detailed annual descriptions of how existing policy is being implemented. $^{6}$

\section{Endnotes}

${ }^{1}$ I am grateful to an anonymous reviewer for this point. See generally Hoppe and Williamson 2018.

${ }^{2}$ Scholarly engagement with the concept is just emerging, see Hilhorst et al. 2018; Lewis 2018.

${ }^{3}$ The enormous amount of policy documentation available on PSEA is outside the scope of this commentary. For an overview of IASC policies, see https://interagencystandingcommittee.org/product-categories/

protection-sexual-abuse-and-exploitation

${ }^{4}$ The idea that criminalization is an appropriate tool to 'end impunity' for sexual violence in conflict is contested (Houge and Lohne 2018; Lemaitre and Sandvik 2014).

${ }^{5} \mathrm{I}$ am grateful to an anonymous reviewer for this observation.

${ }^{6}$ I am grateful to an anonymous reviewer for emphasizing this point.

\section{Acknowledgements \\ I am grateful to anonymous humanitarian workers and peer reviewers providing valuable input for this commentary.}

Funding

Humanitarianism, Borders, and the Governance of Mobility: The EU and the 'Refugee Crisis', funded by the Research Council of Norway 2017-2020. 


\section{Availability of data and materials}

Data sharing not applicable to this article as no datasets were generated or analysed during the current study.

\section{Author's contributions}

The author is sole author. The author read and approved the final manuscript.

\section{Competing interests}

The author declares that she has no competing interests.

\section{Publisher's Note}

Springer Nature remains neutral with regard to jurisdictional claims in published maps and institutional affiliations.

\section{Received: 19 November 2018 Accepted: 27 January 2019} Published online: 18 February 2019

\section{References}

BBC (2018) Oxfam Haiti allegations: how the scandal unfolded, 22 February 2018. https://www.bbc.com/news/uk-43112200. Accessed 10 Jan 2019

Borton, J (2004) The Joint Evaluation of Emergency Assistance to Rwanda. https://odihpn.org/magazine/the-joint-evaluation-of-emergency-assistanceto-rwanda/. Accessed 10 Jan 2019

Bruce-Raeburn, A (2018a) Opinion: Systemic racism and sexism undermine efforts to make aid sector safer, 12 October 2018. https:/www.devex.com/news/ opinion-systemic-racism-and-sexism-undermine-efforts-to-make-aid-sectorsafer-93608. Accessed 10 Jan 2019

Bruce-Raeburn, A (2018b) Opinion: without systemic change, safeguarding will only keep INGOs safe - not people./ 30 May 2018. https://www.devex.com/ news/opinion-without-systemic-change-safeguarding-will-only-keep-ingossafe-not-people-92854

CHS Alliance (2019) Core humanitarian standards. https://www.chsalliance.org/ what-we-do/chs. Accessed 10 Jan 2019

Cornwall A, Brock K (2005) What do buzzwords do for development policy? A critical look at 'participation','empowerment' and 'poverty reduction'. Third World Q 26(7):1043-1060

Dijkzeul D (2015) Heart of paradox: war, rape and NGOs in the DR Congo. In: DeMars WE, Dijkzeul D, editors. The NGO Challenge for International Relations Theory. Abingdon, New York: Routledge, pp 262-286

Dijkzeul D, Sandvik KB (2019) A world in turmoil: governing risk, establishing order in humanitarian crises (disasters)

Duffield M (2016) The resilience of the ruins: towards a critique of digital humanitarianism. Resilience 4(3):147-165

Fairbanks, A (2018) Going local, going safely, 8 August 2018. http://blogs.icrc.org/ law-and-policy/2018/08/08/going-local-going-safely/?utm_source=ICRC+Law +\%26+Policy+Forum+Contacts\&utm_campaign=b439226423-EMAIL_ CAMPAIGN_2018_08_08_12_54\&utm_medium =email\&utm_term =0 8eeeebc66b-b439226423-79444197\&mc_cid=b439226423\&mc_eid= 41a19fec52. Accessed 10 Jan 2019

Gov.UK (2018a) Safeguarding Summit 2018. https://www.gov.uk/government/ topical-events/safeguarding-summit-2018. Accessed 10 Jan 2019

Gov.UK (2018b) International summit to crack down on sexual predators in the aid sector, Department for International Development and The Rt Hon Penny Mordaunt MP. https://www.gov.uk/government/news/international-summitto-crack-down-on-sexual-predators-in-the-aid-sector. Accessed 10 Jan 2019

Hilhorst TDJM, Naik AA, Cunningham AA (2018) International Ombuds for Humanitarian and Development Aid Scoping Study

Hoppe, K, C Williamson (2018) Safeguarding in humanitarian organisations: a practical look at prevention and response https:/odihpn.org/blog/ safeguarding-humanitarian-organisations-practical-look-prevention-response/. Accessed 10 Jan 2019

Houge AB, Lohne K (2018) End impunity! Reducing conflict-related sexual violence to a problem of law. Law Soc Rev 51(4):755-789

Humanitarianwellbeing (n.d.) 'Wellness training for humanitarians', https://www. humanitarianwellbeing.com/wellness-training. Accessed 10 Jan 2019

ICRC (1994) Code of Conduct for the International Red Cross and Red Crescent Movement and Non-Governmental Organizations (NGOs) in Disaster Relief 31-12-1994. https://www.icrc.org/eng/resources/documents/publication/ p1067.htm. Accessed 10 Jan 2019
ICRC (2016) Safeguarding health care: The role of Geneva's permanent missions https:/www.icrc.org/en/document/safeguarding-health-care-role-genevaspermanent-missions. Accessed 10 Jan 2019

IFRC (2018) IFRC and The Nature Conservancy announce new partnership. 12 October 2018. https://media.ifrc.org/ifrc/2018/10/12/ international-federation-red-cross-red-crescent-societies-natureconservancy-team-protect-worlds-vulnerable-coastal-communities/. Accessed 10 Jan 2019

IFRC (n.d.) Youth Policy. https://media.ifrc.org/ifrc/what-we-do/red-cross-and-redcrescent-youth/ifrc-youth-policy/. Accessed 10 Jan 2019

Interaction (2019) CEO pledge on preventing sexual abuse, exploitation, and harassment by and of NGO staff, 03 January 2019, https://www.interaction. org/document/ceo-pledge-preventing-sexual-abuse-exploitation-andharassment-and-ngo-staff. Accessed 10 Jan 2019

iTrack (n.d.) Protecting humanitarian missions. https://www.track-project.eu/ page/media_items/protecting-humanitarian-missions7.php. Accessed 10 Jan 2019

Jacobsen KL, Sandvik KB (2016) Introduction: quest for an accountability cure. In: Sandvik KB, Jacobsen KL. UNHCR and the struggle for accountability. Abingdon, New York: Routledge, pp 11-35

Jahnsen S, Skilbrei ML (2017) Leaving no stone unturned: the borders and orders of transnational prostitution. Br J Criminol 58(2):255-272

Ledgerwood, J (1994) 'UN peacekeeping missions: the lessons from Cambodia. https:// scholarspace.manoa.hawaii.edu/handle/10125/3783. Accessed 10 Jan 2019

Lemaitre J, Sandvik KB (2014) Beyond sexual violence in transitional justice: political insecurity as a gendered harm. Fem Leg Stud 22(3):243-261

Lewis D (2018) Oxfam crisis: we need a more informed debate about NGOs and international aid. In: British politics and policy at LSE http://blogs.lse.ac.uk/ politicsandpolicy/oxfam-crisis-we-need-a-more-informed-debate-about-ngosand-international-aid/. Accessed 10 Jan 2019

Lohne K, Sandvik KB (2017) Bringing law into the political sociology of humanitarianism. Oslo Law Rev 4(01):4-27

Matti S (2015) Governing sexual behaviour through humanitarian codes of conduct. Disasters 39(4):626-647

Merkelbach M, Kemp E (2016) Duty of care: a review of the Dennis v Norwegian Refugee Council ruling and its implications, 21 September 2016. https:// www.eisf.eu/library/duty-of-care-a-review-of-the-dennis-v-norwegian-refugeecouncil-ruling-and-its-implications/. Accessed 10 Jan 2019

Merry SE (2016) The seductions of quantification: measuring human rights, gender violence, and sex trafficking. Chicago: University of Chicago Press

Nadig, A (2012) The sphere project: taking stock. https:/odihpn.org/magazine/ the-sphere-project-taking-stock/. Accessed 10 Jan 2019

Naik A (2002) Protecting children from the protectors: lessons from West Africa. Forced Migr Rev 15:16-19 https://www.fmreview.org/displaced-children-andadolescents/naik. Accessed 10 Jan 2019

Dónal O'Mathúna et al. (2018) Ethics, technology and innovation in humanitarian settings: calibrating the conversation. 5 October 2018. https://ihsa.info/ihsablog/. Accessed 10 Jan 2019

Parker, B (2018) Schemes to stop sex abuse in the aid sector off to a shaky start, 18 October 2018 https://www.irinnews.org/news-feature/2018/10/18/ safeguarding-aid-sector-sex-abuse-shaky-start. Accessed 10 Jan 2019

PROCON.ORG (2018) 100 Countries and their prostitution policies, last updated on: 4/23/2018 https://prostitution.procon.org/view.resource.php?resourcelD= 000772. Accessed 10 Jan 2019

Sandvik KB (2016) How accountability technologies shape international protection: results-based management and rights-based approaches revisited. In: Sandvik KB, Jacobsen KL, editors. UNHCR and the struggle for accountability. Abingdon, New York: Routledge, pp 148-168

Sandvik KB (2018) Technology, dead male bodies, and feminist recognition: gendering ICT harm theory. Aust Fem Law J 44(1):49-69

Sandvik KB (2019) Humanitarians in court: how duty of care travelled from human resources to legal liability. J Legal Pluralism Unofficial Law 1-17. https://doi.org/10.1080/07329113.2018.1548192

Sandvik KB et al (2014) Humanitarian technology: a critical research agenda. Int Rev Red Cross 96(893):219-242

Secretary General (2003) Secretary-General's Bulletin Special measures for protection from sexual exploitation and sexual abuse, 09 October 2003, https://undocs.org/ST/SGB/2003/13. Accessed 10 Jan 2019

Skilbrei ML (2018) Assessing the power of prostitution policies to shift markets, attitudes, and ideologies. Annual review of criminology 
UN High Commissioner for Refugees (UNHCR) (1995) Sexual violence against refugees: guidelines on prevention and response, 8 March 1995, http://www. refworld.org/docid/3ae6b33e0.html. Accessed 19 Nov 2018

World Bank (2016) Review and update of the World Bank's safeguard policies: environmental and social framework. http://documents. worldbank.org/curated/en/748451469107442841/Review-and-update-ofthe-World-Banks-safeguard-policies-environmental-and-social-framework. Accessed 10 Jan 2019

Submit your manuscript to a SpringerOpen ${ }^{\mathcal{O}}$ journal and benefit from:

- Convenient online submission

- Rigorous peer review

- Open access: articles freely available online

- High visibility within the field

- Retaining the copyright to your article

Submit your next manuscript at $\boldsymbol{\wedge}$ springeropen.com 